\title{
The Effectiveness of Change Management in Developing the Organizational Culture of it Darul Azhar
}

\author{
M. Idrus Hasibuan \\ Universitas Islam Negeri Sumatera Utara, Indonesia \\ m.idrushasibuan@uinsu.ac.id
}

\begin{abstract}
This study aims: 1) How to Planning, Organizing, Monitoring and Implementing Change Management 2) What are the steps of the Principal in developing organizational culture 3) What are the supporting and inhibiting factors of the effectiveness of change management in developing organizational culture at SMP IT Darul Azhar Southeast Aceh. This type of research is qualitative. The approach in this study uses a descriptive approach. As informants in this study were the principal, teachers, and students. Research data collection techniques using observation, interviews and documentation. Data analysis techniques used data reduction, data presentation, and drawing conclusions. Techniques to guarantee data validity are credibility, transferability, dependability, and conformability. The results of this study indicate that there are three most important points in the effectiveness of change management in developing the organizational culture of SMP IT Darul Azhar, namely: In change management, the principal is planning according to the needs of students and then by organizing by dividing tasks to teachers to carry out planning, then supervision, namely to know the progress of this change management. In developing the school principal's organizational culture, namely the implementation of morning apples, dhuha prayers, and tadarus al-qur'an after the midday prayers. The supporting factor is the willingness of teachers and students to be better at applying religious values. The inhibiting factor is the lack of competent human resources (HR), loyal to change.
\end{abstract}

Keywords

change management; organizational culture; Darul Azhar

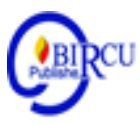

\section{Introduction}

Education as a printing tool for the next generation of a nation is one of the sectors capable of improving human quality. As mandated by the law, that national education functions to develop capabilities and shape the character and character of the nation, aims to develop the potential of students to become human beings who believe in and fear God Almighty, have noble, healthy, knowledgeable, creative, independent character , and become a democratic and responsible citizen (Law on National Education System No. 20. Year 2003).

This implies that all education carried out in the State of Indonesia must lead to achieving these goals. To realize these educational goals, a quality national education system is needed. In the system itself, it is necessary to have a standard of education as a reference, including Change Management in developing an Organizational Culture.

Change has benefits for the survival of an organization, without change, it is certain that the age of the organization will not last long. Changes aim so that the organization does 
not become static but remains dynamic in the face of the times, as well as in the management of an organization.

From several descriptions of change, it can be concluded that change is a necessity that cannot be avoided and is sure to occur even if nothing remains static in this world, everything changes. Likewise, educational institutions, including schools, must also have the ability to change, because schools as educational institutions have a function as an instrument of value transformation, so that they must be able to adapt themselves to the needs, demands, and changes that occur in their environment as an implication of change.

Change management is a systematic process of applying the knowledge, tools and resources needed to influence change in people who will be affected by the process. According to Wibowo (2006: 193) Change management is a systematic process of applying the knowledge, tools and resources needed to influence change in people who will be affected by the process. Meanwhile, according to Pidarta Made (1988: 14), change management is an effort made by a leader or manager in compiling a plan, coordination, direction, control / supervision to achieve goals or objectives that can make an organization or institution become more good from yesterday to achieve goals.

From the above explanation that Change Management is a strategy that must be carried out by a manager in his organization to correct mistakes in the organization being led and to maintain the existence that has been achieved so that the management process which includes planning (planning), organizing (organizing), Leading (leadership and movement), as well as Controling (monitoring and evaluation), can run effectively and efficiently and can lead to progress in accordance with the times.

In this current era, it is not easy for schools to exist properly if they do not have the ability to change themselves quickly and be able to develop in line with various stakeholder demands. These changes can occur within the school itself or outside the school which has implications for changes in schools. The manifestation of changes that occur within schools such as changes in organizational culture.

This condition certainly demands a change in the school culture or organization because changes that occur in schools do not change directly but there is a process of changing school culture. For example, changing the curriculum is of course not enough to only change the curriculum, but what is more important than that is to change the mind-site / mindset of all school members, especially teachers. Changes in this way of thinking will then affect changes about the various values in schools which in turn will also affect changes in school culture.

Therefore, change management is needed so that changes that occur in schools are truly built together from the shared values of school members so that the impact of these changes can be directed at positive points of change. The ability of schools to change is determined by how empowered the school community is in making changes and managing change.

Darul Azhar School is located in Deleng Megakhe Village, Badar District, Southeast Aceh Regency. SMP IT Darul Azhar was founded in 2008, which was founded by Tgk. H. Imran Arif Sya'ban, Lc, in which there are 2 formal educational institutions, namely SMP IT and Madrasah Aliyah, the number of students at SMP IT Darul Azhar was around 50 students. In daily teaching and learning activities, this school uses limited facilities due to lack of funding. Funding sources are generally taken from contributions from parents of students and from assistance from agencies, as well as voluntary and non-binding donors. The parents of students also do not have more sources of income, on average the community (parents) work as farmers, with a variety of agricultural production. 
Along with the development of the era of SMP IT Darul Azhar continues to innovate to increase the quality, quantity, capacity of students, teachers, ustadz, ustadzah and facilities and infrastructure, currently the number of students there are 285 (Two Hundred Eighty Five) IT SMP level students. The enthusiasm of the community around the school and in the subdistrict environment generally decreases, this is indicated by the decrease in the number of students each year.

This is what needs to be considered about the organizational culture of SMP IT Darul Azhar is a value that is set to be adhered to by everyone in the school and used as a habit with the aim of achieving the vision and mission of the school, which is usually also called the school sunnah. There are regulations such as school rules in general, for example students are not allowed to smoke, students do not have long hair and tattoos, are obliged to protect the environment, must participate in every school activity such as scientific traditions at Darul Azhar school, there are daily activities of students every morning and evening and at night there are recitation activities and deliberations. In recitation activities, students study sciences such as Islamic religious education, the Koran and hadith.

Darul Azhar School has the authority to recruit and select, new students are not fully indoctrinated into the organizational culture. Because you are not familiar with the organizational culture, it may have the potential to disrupt existing traditions and habits. Therefore the school must help the new students adapt to their culture. For example, all students must clean the school environment every morning and evening. Students must have initial characteristics, namely ready to be tired, ready to work together. This is where the students show their commitment.

SMP IT Darul Azhar Aceh Tenggara is an educational institution that formed and gave birth to a strong, creative, and global-minded generation of Robbani. This educational institution helps students to recognize and optimize the potential that exists in each student, both intellectually, emotionally, and spiritually and to form a generation that is trustworthy, istiqomah, and has high morality.

Management of change carried out by the principal at SMP IT Darul Azhar Aceh Tenggara uses managerial skills, while what is meant by managerial skills in carrying out the change process includes two strategies that can be applied in school organizations. The first is structurally, where organizationally, the Principal can place staff who have the vision and desire with adequate skills to make changes towards the organizational goals to be achieved, in a strategic position as agents of change.

Of course, this must be accompanied by strong data and rationale so that there are no rumors that the Principal only appoints staff close to him. The second thing that can be done is to manage human resources in the school to be empowered in the change process in order to achieve the school's strategic goals as an organization. This requires a variety of performance appraisal tools, "knowledge management" and an analysis of the needs for human resource development within the school. In addition, skills in conducting "coaching" and "mentoring" will greatly assist the Principal in carrying out the change management process in the school he leads. According to Pidarta (1998: 97) the principal is the key to the success of the school in making change. So that activities to improve and improve the program and learning process at school mostly lies with the Principal himself. Pidarta states that the Principal has roles and responsibilities as education manager, education leader, education supervisor, and education administrator. Likewise, the development and progress achieved by SMP IT Darul Azhar Aceh Tenggara cannot be separated from the role of the Madrasah Principal as the leader of the school. 
The leadership patterns used by the Principal in managing this school are proven to have made a positive contribution or contribution to development and progress in the future. SMP IT Darul Azhar Aceh Tenggara is a school whose existence has received quite a positive response from the community, with evidence that the community is sending their children to this school, from the data I got it was recorded that in 2020 there were 285 students who attended the school, this number is the number the largest number of students from other private schools in Kutacane, Aceh Tenggara. In addition, the number of students has decreased each year,

This change management is in line with the implementation of daily activities in Darul Azhar school which want to be an organizational culture that must be maintained, therefore to maintain the desired organizational culture requires change management of school principals that ensure the implementation of organizational culture in schools, researchers also describes the organizational culture that must be maintained and developed into the competitiveness of education in Southeast Aceh.

Culture of the Learning System The next peculiarity of the learning system at SMP IT Darul Azhar Aceh Tenggara is the Muajjih activity, which is a night study which culminates in a general exam for both the national exam and the pesantren exam itself. That night was like a night market because the whole place was filled with students and students repeating lessons. The results of this study of findings from SMP IT Darul Azhar Aceh Tenggara can be concluded that: SMP IT Darul Azhar Aceh Tenggara provides religious education in the form of an integrated Islamic school and teaches general sciences and implements the national curriculum from the ministry of religion, school and school relations and its management are integrated.

Religious culture Sunnah fasting on Mondays and Thursdays is carried out by all students and students to train patience, the implementation of other routine worship such as Tadarrus al-Quran and evening prayers is carried out by reciting together in the mosque. The recitation of the Koran is carried out jointly or independently, independently as well as to memorize and Muroja'ah Juz 30, for students and students who want to deepen memorization, the extra institution Jamiyatul Qurra Wal Huffaz (JQH) is a means for this. . The implementation of other services is the incidental Tahajjud prayer if there is an intention from the boarding school such as the Islamic boarding school's birthday, 1 Muharram, students and students of class IX will take their national final exams to carry out the Tahajjud prayer.

Culture of Life Skill (Life Skills) Usually carried out by students and students of class IX in the even semester until before class IX in the odd semester which is being mandated by the pesantren to manage OSDAM (Darul Azhar Modren Student Organization), including Pencak Silat, Scouts, Computers, Calligraphy, Speeches, Fardu Kifayah, Dance and Art, Sports, including Islamic boarding schools including cooperatives, student shops and so on. According to one ustadz, the shop's profit in the last 3 years has been two million rupiah. The coordination was brought under the guidance of the Southeast Aceh District Cooperative Office. Students and students who are only guarding are not entitled to take financial gain. The advantage of students and santriwati is the knowledge of life skills from SMP IT Darul Azhar Aceh Tenggara.

\section{Research Methods}

This research was conducted at SMP IT Darul Azhar which is located in the village of Deleng megakhe, Badar District, Southeast Aceh Regency. The research was carried out 
from 20 August - 13 September 2020. The research subjects in this study were the Principal, Teachers, and Students. Data collection techniques used in this study were observation, interviews and documentation. The data analysis techniques used include data reduction, data presentation, and conclusion drawing. This analysis is involved in an interrelated process, so as to find the final result of the data research that is presented systematically based on the formulated themes. Techniques for ensuring the validity of data in scientific research are data triangulation, method triangulation, investigative triangulation, and theory triangulation.

\section{Discussion}

Based on the research findings, there is a big role for leaders in the process of achieving the goals of educational institutions. Thus, it can be said that the success or failure of educational institutions is largely determined by the quality of their leaders. Both related to the quality of personality as well as concepts and effective leadership techniques in an educational institution. The success of the headmaster in carrying out his duties, depends on the way of leadership.Planning carried out by the principal of SMP IT Darul Azhar Southeast Aceh focused on the learning process during the pandemic, where the principal conducted an analysis of student needs first, after knowing the student's needs the principal took action by making changes to the learning process, namely by using WhatsApp, zoom, and make interesting applications as well as using quizzes and googleform and this planning is done by holding a meeting first with the teachers regarding the existing changes.

The organizing that was carried out by the principal of SMP IT Darul Azhar Aceh Tenggara was to conduct training related to online learning by inviting resource persons. Which aims to provide enthusiasm and motivation for teachers so that teachers can more easily make teaching materials for students and the learning process goes well even though online.

The supervision of the principal of SMP IT Darul Azhar, Southeast Aceh, is very firm because that is where the principal asks for reports on the duties of students to each subject teacher. The school principal wants this online learning process to run according to a predetermined plan, according to the principal, supervising each subject teacher must be very strict because if not supervised, each subject teacher can be negligent or lazy with responsibility. So the principal does not tire of giving motivation or encouragement to teachers and students to be enthusiastic in online school.

The implementation of change management in developing online learning is of course done by planning first, then there must be organization and supervision described by the researchers above. Of all the processes described above, the implementation of change management in online learning at SMP IT Darul Azhar is right even though there are still some teachers who don't really understand the implementation, this has been proven by several good findings in terms of the form of implementing changes related to online learning is both in terms of time and facilities. In terms of time, learning was done face-to-face because of the pandemic, so it was done remotely, but the time was still the same as face to face. This can make students maintain their health and not play too much, and can follow health protocols from the government. Regarding the target, before there was a pandemic where teaching and learning activities were carried out face-to-face, and it was different from today because of the Covid 19 pandemic so the teaching and learning system had to be online and remotely. This certainly can encourage every teacher to be 
more diligent and active in mastering technology. Even though during the Covid pandemic 19 school principals continued to pay attention to organizational culture through WhatsApp, there were steps the principal took in developing organizational culture. Due to the COVID-19 pandemic, the Principal of SMP-IT Daru Azhar paid attention to and supervised the activeness of students and the presence of students in learning using the WhatsApp application which, according to him, was very effective in communicating with teachers. Then for the steps of the principal in developing an organizational culture in students, namely starting from planning, implementing and supervising culture, it has been established jointly with the teacher and student councils. As for the form of organizational culture, namely praying together at morning apples and shaking hands with the teacher, praying dhuha together when resting and students are not allowed to be in the canteen before performing dhuha prayers, then praying noon together accompanied by tadarrus AlQur'an between students and teachers.

The researcher saw by observing that the implementation of this culture was going well, the situation in the field was in accordance with the results of the interview above, it was just not effective because there were still students that the researchers saw were in the canteen when the above activity was taking place.

Supporting factors for change management in developing organizational culture, namely due to the demands of national education and the 2013 curriculum which emphasizes moral or ethical improvement in students so as to encourage school principals to make changes to organizational culture in order to improve students' worship abilities and student social science, then that becomes a supporting factor is a necessity in society, namely the need for a young generation who has an Islamic insight and is able to implement religious values such as morals, is able to pray and be an example for the community in worship. Likewise for students who are very supportive of this change in order to increase their ability to carry out worship.

The inhibiting factor of implementing changes in this organizational culture is the lack of competent, loyal and fully supportive human resources because according to the principal of SMP-IT Darul Azhar there are still teachers who are not in the mosque together with students to implement this culture, however, the principal will evaluate and find solutions to these existing problems.

\section{Conclusion}

The principal at SMP IT Darul Azhar is a leader who always directs, nurtures, all members so that they always strive to create competent changes in their fields to develop a school organizational culture. And after observations and interviews with the principal of SMP IT Darul Azhar have been effective in change management in developing the school organizational culture, the principal made changes starting fromPlanning carried out by the principal of SMP IT Darul Azhar Southeast Aceh focused on the learning process during the pandemic, where the principal conducted an analysis of student needs first, after knowing the student's needs the principal took action by making changes to the learning process, namely by using WhatsApp, zoom, and make interesting applications and use quizzes and googleform. The organizing that was carried out by the principal of SMP IT Darul Azhar Aceh Tenggara was to conduct training related to online learning by inviting resource persons. Which aims to provide enthusiasm and motivation for teachers so that teachers can more easily make teaching materials for students and the learning process goes well even though online. The organizing that was carried out by the principal of SMP 
IT Darul Azhar Aceh Tenggara was to hold training related to online learning, namely by inviting resource persons. Supervision of the principal of SMP IT Darul Azhar Aceh Tenggara was very strict because that is where the principal asked for reports on the duties of students to each subject teachers.

The steps of the principal in developing an organizational culture. Due to the COVID-19 pandemic, the Principal of SMP IT Daru Azhar paid attention to and supervised the activeness of students and the presence of students in learning using the WhatsApp application which, according to him, was very effective in communicating with teachers. Then for the steps of the principal in developing an organizational culture in students, namely starting from planning, implementing and monitoring the culture that has been established together with the teacher and student councils. As for the form of organizational culture, namely praying together at morning apples and shaking hands with the teacher, praying dhuha together when resting and students are not allowed to be in the canteen before performing dhuha prayers, then praying noon together accompanied by tadarrus Al-Qur'an between students and teachers.

Supporting factors for change management in developing organizational culture, namely due to the demands of national education and the 2013 curriculum which emphasizes moral or ethical improvements in students so as to encourage school principals to make changes to organizational culture in order to improve students' worship abilities and student social science, then that becomes a supporting factor. is a necessity in society, namely the need for a young generation who has an Islamic insight and is able to implement religious values such as morals, is able to pray and be an example for the community in worship. Likewise for students who are very supportive of this change in order to increase their ability to carry out worship.

The inhibiting factor of implementing changes in this organizational culture is the lack of competent, loyal and fully supportive human resources because according to the principal of SMP-IT Darul Azhar there are still teachers who are not in the mosque together with students to carry out this culture, however, the principal will evaluate and find solutions to these existing problems.

\section{References}

Abdillah. (2010). Sekolah unggul dan pengendalian mutu pendidikan. Hijri: Jurnal Manajemen Kependidikan dan Keislaman, III (1). pp. 1-13. http://repository.uinsu.ac.id/325/

Arto Suharto Prawirodirdjo, (2007). Analisis Pengaruh Perubahan Organisasi dan Budaya Organisasi terhadap Kepuasan dan Kinerja Pegawai Direktorat Jenderal Pajak, Diponegoro Semarang.

Chaniago, Nasrul Syakur dan Amiruddin, (2016). Organisasi Manajemen, Jakarta: PT raja Grafindo Persada.

Davis, dan Newstrom, John. Behavior, Human at Work, (2002): Organizational Behaviori. Singapura: McGraw-Hill International. Inc.

Depdikbud, Kamus Besar Bahasa Indonesia, (1998), Jakarta: Balai Pustaka.

Djokosantoso, dan Moeljono, (2005). Budaya Organisasi dalam Tantangan, Jakarta: PT Elex Media Komputindo.

Dwi, Hamidah, (2013) Karakteristik Budaya Organisasi Unggul Sebagai Upaya Meningkatkan Kinerja Perusahaan, Surakarta: Skripsi Fakultas Ekonomi dan Bisnis.

Hasibuan, Malayu S.P, (2004). Dasar-Dasar Perbankan, Jakarta: Bumi Aksara. 
Hidayat, Rahmat dan Rifa'i, Muhammad, (2018). Etika Manajemen Perspektif Islam, Medan: LPPPI.

Idrus, Achmad, (2015). Pengantar Manajemen, Medan: Perdana Publishing.

Jiman, (2011). Manajemen Perubahan Dalam Pengelolaan Laboraturium Ilmu Pengetahuan Alam,FKIP Universitas Bengkulu.

Munajat, Imam, (2016). Manajemen Perubahan Pendidikan, UIN SGD Bandung.

Nurdin, Ismail, (2012). Budaya Organisasi, Malang, UB Press.

Nurdin, Ismail, (2012). Budaya Organisasi Konsep, Teori dan Implementasi, Malang: UB Press.

Noor, Juliansyah. Penelitian Ilmu Manajemen Tinjauan Filosofis dan Praktis. Jakarta: Kencana Prenada Media group.

Kemenag RI, (2015). Al-Qur'an dan 'Terjemahannya, Jakarta, Maktabah.

Made, Pidarta, (1988). Manajemen Pendidikan Indonesia. Jakarta: Bumi Aksara.

Moelong, Lexy J, (2006). Metode Penelitian Kualitatif Edisi Revisi, Bandung: Remaja Rosdakarya.

Nasution, Nur, (2010). Manajemen Perubahan, Bogor: Ghalia Indonesia.

Mesiono, (2012). Manajemen dan Organisasi, Bandung, Citapustaka Media Printis.

Moleong, Lexy .J, (2005). Metodologi Penelitian Kualitatif, Bandung: Remaja Rosdakarya.

Rifa'i, Muhammad, dan Fadhli, Muhammad, (2013). Manajemen Organisasi, Bandung, Citapustaka Media Perintis.

Pasmore, (1994). Creating Strategic Change, New York: Jhon Wiley \& Sons.

Widi, Restu Kartiko, (2010). Asas Metodologi Penelitian Sebuah Pengenalan dan Penuntun Langkah demi Langkah Pelaksanaan Penelitian, Yogyakaerta: Graha Ilmu.

Robbins dan Coulter, (2001). Organization Behavior, New Jersey: Prentice

Hall International.

Ananda, Rusydi, Banurea, Oda Kinata, (2017). Menajemen Sarana Dan Prasarana Pendidikan Medan:wid ya puspita.

Salim, dan Syahrum, (2007). Metodologi Penalitian Kualitatif. Bandung: Citapustaka Media.

Salim, (2016). Metodologi Penelitian Kualitatif. Bandung: Cita Pustaka.

Sarosa, Samiaji, (2012). Penelitian Kualitatif: Dasar-dasar, Jakarta: PT. Indeks.

Asiah, Siti, (2017). Dasar Ilmu Manajemen, Yogyakarta: Mahameru Press.

Sugiyono, (2006). Metode Penelitian Kualitatif, Kualitatif dan R\&D, Bandung: PT. Remaja Rosdakarya.

Sugiyono, (2006). Metode Penelitian Kualitatif, Kualitatif dan R\&D, Bandung: PT. Remaja Rosdakarya.

Sugiyono, (2017). Metode Penelitian Pendidikan, Bandung: Alfabeta.

Arikunto, Suharsimi, (1998). Prosedur Penelitian Suatu Pendekatan Praktek, (Jakarta: Rineka Cipta.

Undang-undang No. 20 Tahun 2003 Tentang Sistem Pendidikan Nasional, Ban II Pasal 3. Wahab, (2011). Anatomi Organisasi dan Kepemimpinan Pendidikan,Bandung: Alfabeta.

Wibowo, (2013), Budaya Organisasi, Jakarta: PT RajaGrafindo Persada,

Winardi, (2004). Manajemen Perubahan Manajemen of change, Bandung: Kencana.

Wijaya, Candra dan Rifa'i, (2016). Dasar-Dasar Manajemen, Medan: Perdana Publishing. 